\title{
PENGARUH STRATEGI JOYFUL LEARNING DENGAN TEKNIK MIND $M A P$ TERHADAP HASIL BELAJAR KOGNITIF PESERTA DIDIK KELAS XI IPA SMA NEGERI 6 BANDAR LAMPUNG
}

\author{
${ }^{1}$ Marlina Kamelia, ${ }^{2}$ Ahmad, dan ${ }^{3}$ Yeni Novitasari \\ ${ }^{1,2}$ Universitas Islam Negeri Raden Intan Lampung. Jl. H Endro Suratmin \\ Sukarame-Bandar Lampung (0721) 70326 : marlina@gmail.com
}

Diterima : 07 Agustus 2017. Disetujui: 11 Desember 2017. Dipublikasikan: 29 Desember 2017

\begin{abstract}
ABSTRAK
Pendidikan merupakan suatu modal penting bagi seseorang untuk menjalani kehidupannya. Penelitian pada kali ini juga dilatar belakangi oleh rendahnya rataan hasil belajar kognitif peserta didik. Hasil belajar yang rendah tersebut disebabkan karena tingkat pemahaman konsep yang kurang sehingga nilai yang diperoleh peserta didik banyak yang tidak memuaskan. Selain kemampuan untuk memahami, hubungan kerjasama dan tingkat kecerdasan antar peserta didik yang masih kurang tersebut bisa membuat proses pembelajaran menjadi kurang kondusif. Kecerdasan ini belum dimunculkan saat proses pembelajaran, karena salah satu contoh kecerdasan antar pribadi adalah kemampuan untuk memahami dan bekerjasama satu sama lain. Salah satu strategi yang bisa digunakan adalah dengan menerapkan strategi joyfull learning atau pembelajaran yang menyenangkan menggunakan mind map.

Penelitian ini bertujuan untuk mengetahui apakah ada pengaruh strategi joyfull learning dengan teknik mind map terhadap hasil belajar kognitif khususnya materi sistem ekskresi di SMA Negeri 6 Bandar Lampung. Jenis penelitian quasy eksperimental dengan jenis nonequivalent control group design. Populasi dalam penelitian ini adalah peserta didik kelas XI SMA Negeri 6 Bandar Lampung dengan sampel penelitian terdiri dari 2 kelas yang diperoleh menggunakan tehnik Cluster Random Sampling. Kelas eksperimen XI IPA 1 dan kelas kontrol XI IPA 3. Teknik pengumpulan data observasi, tes (pretest dan posttest) dan dokumentasi. Hasil penelitian dan pembahasan perhitungan uji t independent dengan sampel tidak berkorelasi diperoleh bahwa $t_{\text {hitung }}=3,625$ dan $t_{\text {tabel }}=2,001$. Hal ini berarti bahwa $t_{\text {hitung }}$ lebih besar dari $t_{\text {tabel }}$ sehingga dapat disimpulkan bahwa terdapat pengaruh strategi joyfull learning dengan teknik mind map terhadap hasil belajar kognitif peserta didik kelas XI IPA SMA Negeri 6 Bandar Lampung pada materi sistem ekskresi setelah diberi perlakuan. Peningkatan hasil belajar tersebut dipengaruhi oleh faktor eksternal seperti penggunaan strategi pembelajaran juga disebabkan oleh faktor internal seperti kemampuan kognitif yang bisa mempengaruhi daya ingat pada peserta didik saat proses pembelajaran berlangsung.
\end{abstract}

Kata kunci: Strategi Joyfull learning, Mind Map, dan Hasil Belajar Kognitif 


\section{PENDAHULUAN}

Peran pendidikan tidak terlepas dari komponen-komponen peserta didik, guru, materi pembelajaran, media pembelajaran, model pembelajaran, dan lain sebagainya. Faktor utama dalam pendidikan yang dijelaskan tersebut perlu ditingkatkan kualitasnya sebab maju mundurnya peradaban masyarakat atau bangsa terletak pada tingkat pendidikan. Pendidikan perlu mendapatkan perhatian, penanganan, prioritas dari pemerintah, masyarakat maupun pengelola pendidikan agar tercapainya tujuan yang diharapkan. Tujuan dalam proses belajar mengajar dapat tercapai dengan diterapkannya suatu strategi yang tepat yang dapat mempengaruhi proses pembelajaran. Hal ini sejalan dengan tujuan sistem pendidikan nasional berikut:

” Menurut UU No. 20 Tahun 2003, tentang sistem pendidikan nasional, pendidikan adalah usaha sadar dan terencana untuk mewujudkan suasana belajar agar peserta didik secara aktif mengembangkan potensi dirinya untuk memiliki kekuatan spiritual keagamaan, pengendalian diri, kepribadian, kecerdasan, akhlak mulia, serta ketrampilan yang diperlukan dirinya, masyarakat, bangsa dan Negara ( Suparyo, 2005). Berdasarkan tujuan pendidikan nasional tersebut kita dapat melihat bahwa komponen yang dicita-citakan dalam tujuan pendidikan nasional tersebut semuanya berupa nilai, keberhasilan dalam proses belajar mengajar antara pendidik dan peserta didik.

Kemampuan kognitif penting karena berhubungan dengan hasil belajar, tanpa adanya fungsi kognitif siswa tidak akan mampu untuk memahami apa yang 
disampaikan guru. Proses pembelajaran kognitif lebih mementingkan proses belajar dari pada hasil belajarnya, karena belajar tidak sekedar melibatkan hubungan antara stimulus dan respon melainkan tingkah laku seseorang ditentukan oleh persepsi serta pemahamannya tentang situasi yang berhubungan dengan tujuan belajarnya (Mulyana, 2016) .

Mata pelajaran biologi merupakan mata pelajaran wajib bagi peserta didik yang mengambil jurusan IPA dan harus diberikan serta mata pelajaran yang diuji secara nasional. Sejalan dengan Tujuan Pendidikan Nasional, tujuan pendidikan biologi dalam kurikulum biologi di SMA antara lain dapat memahami konsep, keterampilan dalam mengamati, dan memilih informasi faktual yang relevan.

Berdasarkan tujuan tersebut maka dapat disimpulkan bahwa biologi memiliki tujuan untuk meningkatkan kemampuan kognitif. Kemampuan kognitif yaitu penampilan yang dapat diamati dari aktifitas mental (otak) untuk memperoleh pengetahuan melalui pengalaman sendiri.

Hasil pembelajaran IPA juga dipengaruhi oleh penggunaan strategi, metode maupun teknik yang digunakan oleh pendidik. Strategi yang baik adalah apabila pendidik tersebut mampu membuat suasana pembelajaran menjadi menarik dan menyenangkan. Mengimplementasikan sebuah metode, setiap orang bisa berbeda tergantung pada teknik dan gaya masing-masing pada setiap orang. Media yang digunakanpun sangatlah penting sehingga bisa tercapainya hasil 
pembelajaran yang baik ketika peserta didik mempelajari materi yang disampaikan.

Faktor eksternal seperti sarana dan fasilitas tersebut akan mengarahkan peserta didik saat belajar dan akan terlihat pada saat proses pembelajaran berlangsung. Salah satu faktor eksternal yang dapat mempengaruhi hasil belajar adalah faktor lingkungan fisik kelas. Lingkungan kelas yang kondusif, nyaman, menyenangkan dan bersih beperan penting dalam menunjang keefektivan belajar. Faktor internal seperti ranah kognitif bisa mempengaruhi hasil belajar pada peserta didik. Kemampuan intelektual berhubungan dengan pengetahuan, ingatan, pemahaman dan analisis (Hamalik, 2011).

Proses pembelajaran yang baik tidak akan terlepas dari komponenkomponen proses pembelajaran yaitu, aspek strategi (strategi, pendekatan, metode, tehnik dan taktik), media ( modul, buku, LKS), dan aspek evaluasi. Ketiga aspek tersebut harus ada dalam proses pembelajaran karena pemilihan strategi yang digunakan akan berpengaruh pada hasil belajar yang tentunya didukung dengan media sehingga seluruh kegiatan akan sangat menarik. Kegiatan belajar mengajar dijamin menyenangkan dan hasil belajar peserta didik bisa memperoleh nilai yang baik dan memuaskan.

Berdasarkan hasil pra penelitian yang dilakukan peneliti di SMA Negeri 6 Bandar Lampung, peneliti menemukan bahwa rendahnya hasil belajar kognitif peserta didik dapat diketahui dari hasil rata-rata nilai ulangan harian Biologi 
kelas XI IPA SMA Negeri 6 Bandar Lampung pada materi "Sistem Pernapasan" di SMA Negeri 6 Bandar Lampung sebagai berikut :

Tabel 1

Daftar Nilai Kognitif Hasil Belajar Ulangan Harian Peserta Didik Kelas XI Semester Genap SMA 6 Bandar Lampung Tahun Pelajaran 2015/2016

\begin{tabular}{|c|c|c|c|c|c|c|c|c|}
\hline \multirow{2}{*}{ No } & \multirow{2}{*}{$\begin{array}{l}\text { Nilai } \\
\text { KKM }\end{array}$} & \multirow{2}{*}{ Interval } & \multicolumn{3}{|c|}{ Kelas XI IPA } & \multirow{2}{*}{$\begin{array}{l}\text { Jumlah Total } \\
\text { Peserta Didik }\end{array}$} & \multirow{2}{*}{ Presentase } & \multirow{2}{*}{$\begin{array}{l}\text { Presentase } \\
\text { Kumulatif }\end{array}$} \\
\hline & & & IPA1 & IPA2 & IPA3 & & & \\
\hline 1 & \multirow{2}{*}{$>70$} & $80-100$ & 4 & 2 & 1 & 7 & $7.78 \%$ & \multirow{2}{*}{$\begin{array}{l}24,40 \% \\
\text { Tuntas. }\end{array}$} \\
\hline 2 & & $70-79$ & 6 & 7 & 2 & 15 & $16.67 \%$ & \\
\hline 3 & \multirow{3}{*}{$<70$} & $60-69$ & 3 & 4 & 11 & 18 & $20 \%$ & \multirow{4}{*}{$\begin{array}{l}64 \% \\
\text { Belum } \\
\text { Tuntas }\end{array}$} \\
\hline 4 & & $50-59$ & 9 & 13 & 7 & 29 & $32.2 \%$ & \\
\hline 5 & & $<49$ & 8 & 4 & 9 & 21 & $23.3 \%$ & \\
\hline \multicolumn{3}{|c|}{ Jumlah } & 30 & 30 & 30 & 90 & $100 \%$ & \\
\hline
\end{tabular}

Sumber: Buku Nilai Guru Biologi SMA Negeri 6 Bandar Lampung

Berdasarkan hasil observasi dan pengumpulan data terlihat bahwa hasil belajar seluruh peserta didik kelas XI IPA SMAN 6 Bandar Lampung masih rendah. Tahun ajaran 2015/2016 sebanyak 90 peserta didik dengan presentase nilai diatas 70 sebesar $24 \%$ sedangkan nilai di bawah 70 sebesar $64 \%$. Hasil belajar yang rendah tersebut disebabkan karena tingkat pemahaman konsep yang kurang sehingga nilai yang diperoleh peserta didik banayak yang tidak memuaskan. Sesuai data di atas dapat diketahui bahwa hasil belajar peserta didik masih dalam kategori rendah. Hal ini dikarenakan pada saat belajar kurang memperhatikan guru yang menjelaskan serta keterlibatan peserta didik dalam kegiatan belajar mengajar yang masih kurang optimal.

Masalah lain yang dijumpai dalam pembelajaran diantaranya pembelajaran yang diterapkan oleh pendidik tidak ditunjang dengan sumber yang relevan, cara penyampaian pendidik tidak menggunakan strategi, metode maupun teknik yang baik sehingga yang berperan aktif adalah pendidik. Proses 
pembelajaran di kelas tersebut berlangsung sangat kaku dan kurang kondusif. Padahal peserta didik mengharapkan belajar yang menyenangkan, sebab jiwa mereka mengetahui dengan cara-cara menyenangkan akan menyeimbangkan otak kanan dan otak kiri. Pendidik juga kurang memberikan suasana pembelajaran yang baru sehingga timbul kebosanan bagi peserta didik. Proses pembelajaranpun menjadi kurang efektif dan hasil belajar yang diperoleh tidak memuaskan.

Peserta didik juga kurang memperhatikan penjelasan dari guru, hal tersebut tampak ketika guru memberikan pertanyaan, peserta didik tidak bisa menjawab, karena tidak membaca atau mempelajari materi sebelum memulai pelajaran tersebut. Guru menjelaskan materi pelajaran sedangkan peserta didik sibuk sendiri dengan kegiatan masing-masing. Kemampuan untuk memahami dan bekerjasama antar peserta didik yang masih kurang bisa menyebabkan pembelajaran menjadi kurang kondusif.

Suasana pembelajaran menyenangkan dapat diciptakan bila guru menyadari bahwa materi yang dipelajari akan melekat lebih lama dalam otak peserta didik jika suasana tidak kaku akan lebih bermakna bagi anak. Setiap kecerdasan peserta didik mempunyai proses kognitif yang terpisah dalam bidang memori, perhatian, persepsi, pemahaman dan pemecahan masalah ( Yuberti: ,2012). Tingkat pemahaman peserta didik belum memuaskan dapat dilihat dari nilai hasil belajar yang rendah akan menyebabkan kecerdasan antarpribadi menjadi kurang. Kecerdasan antarpribadi adalah kemampuan untuk memahami 
dan bekerjasama dengan orang lain( Darmansyah, ,2011). Kecerdasan in belum muncul pada saat proses pembelajaran berlangsung.

Kenyataan tersebut menyebabkan banyak peserta didik yang yang hasil belajarnya kurang memuaskan. Strategi maupun metode yang diimplementasikan oleh pendidik selama ini belum mendukung peningkatan hasil belajar peserta didik. Fenomena di atas adalah masalah-masalah yang dijumpai di kelas XI IPA SMA Negeri 6 Bandar Lampung. Akibat tidak diterapkannya sebuah strategi yang baik dan tentunya didukung dengan media yang baik juga akan berdampak terhadap hasil belajar yang diperoleh peserta didik.

Salah satu cara untuk meningkatkan hasil belajar adalah dengan menerapkan strategi pembelajaran menyenangkan (joyfull learning) sehingga tercapainya lingkungan belajar yang menyenangkan pada materi sistem ekskresi. Meningkatkan daya ingat dan hubungan momunikasi antar peserta didik bisa mempengaruhi hasil belajar pada peserta didik. Suasana seperti ini akan memberikan kontribusi terhadap peningkatan hasil belajar. Penggunaan teknik mind map juga diharapkan akan membantu peserta didik untuk mendapatkan hasil belajar yang memuaskan.

Mind map sangat baik digunakan oleh pendidik untuk meningkatkan daya hafal peserta didik dan pemahaman konsep ekskresi pada saat pembelajaran berlangsung dan tentunya berpengaruh pada hasil belajar. Sistem ekskresi adalah proses pengeluaran zat sisa hasil metebolisme yang tidak 
digunakan lagi oleh tubuh yang dikeluarkan bersama urin, keringat atau pernapasan (Amin, 2012).

Joyfull learning adalah suatu pola berpikir dan arah berbuat yang diambil oleh pendidik dalam memilih dan menerapkan cara-cara penyampaian materi sehingga mudah dipahami dan memungkinkan tercapainya suasana pembelajaran yang tidak membosankan. Hal ini sejalan dengan pernyataan lebih lengkap bahwa strategi pembelajaran menyenangkan adalah strategi yang digunakan untuk menciptakan lingkungan belajar yang efektif, menerapkan kurikulum, menyampaikan materi dan memudahkan proses belajar.

Strategi joyfull learning perlu dipahami secara luas pembelajaran menyenangkan bukan berarti selalu diselingi dengan lelucon, humor, banyak bernyanyi atau tepuk tangan yang meriah. Peserta didik merasa nyaman, aman dan asyik, sehingga perasaan yang mengasyikkan tersebut mengandung unsur keingintahuan yang disertai upaya mencari tahu sesuatu. Proses pembelajaran yang dilakukan haruslah menyenangkan, aman, santai/rileks, penjelajahan (eksploratory), menggembirakan serta perlu memperhatian aspek yang ada di dalamnya( Darmansyah, 2011).

Aspek yang perlu diperhatikan dalam pembelajaran menyenangkan diantaranya lingkungan fisik, interaksi antara pendidik dengan peserta didik dan suasana belajar memberikan peluang terciptanya kondisi belajar yang kondusif (Darmansyah, 2011). Ketiga faktor tersebut memberikan dampak yang baik terhadap kesenangan belajar peserta didik tergantung situasi dan kondisi yang 
ada di dalam kelas. Perlunya pemilihan strategi yang baik oleh pendidik penting artinya dalam meningkatkan efektivitas pembelajaran yang menyenangkan dan penggunaan metode diskusi dengan teknik mind map akan mendukung situasi pembelajaran yang menyenangkan. Situasi tersebut dapat membangun hubungan dan meningkatkan komunikasi antara pendidik dan peserta didiknya, sebagai alat pengurang stress dan meningkatakan daya ingat peserta didik.

Tony Buzan adalah orang yang membuat dan mengembangkan mind map yang sangat mudah diimplementasikan. Mind map atau peta pikiran adalah sebuah teknik yang memudahkan untuk menggambar bagaimana otak bisa mencari dan menemukan ide dalam jumlah yang besar dalam waktu yang singkat. Peran atau posisi guru dalam pembelajaran dengan menggunakan mind map adalah sebagai fasilitator, pembimbing atau penasehat belajar (Hendry, 2011). Media ini akan membantu dalam penyajian awal dalam pembelajaran biologi sehingga peserta didik dapat menyerap materi secara optimal dan mencapai tujuan yang diharapkan.

Menggunakan teknik mind map ini guru dapat menyampaikan materi pelajaran yang rumit menjadi mudah, selain itu anak didik pun mampu menyerap materi pelajaran karena disampaikan dengan cara yang sangat sederhana, padat dan jelas. Penggunaan kertas, warna, garis, lambang, gambar, kata-kata, berdasarkan seperangkat aturan yang sederhana, mendasar, alami akan memudahkan otak dalam menyerap informasi yang diterima. 
Teori kognitif menyatakan bahwa hasil belajar merupakan bukti usaha yang dilakukan dalam kegiatan belajar dan merupakan nilai yang diperoleh oleh peserta didik dari proses belajar mengajar. Ketercapaian suatu tujuan pembelajaran dapat dilihat dari hasil belajar peserta didik melalui tes. Berdasarkan uraian di atas tes formatif dilaksanakan untuk mengetahui apakah peserta didik sudah menguasai konsep secara menyeluruh atau belum. Ranah kognitif berkenaan dengan hasil belajar yang intelektual terdiri dari enam aspek yaitu hasil belajar, pengamatan, hafalan, analisis, sintesis dan evaluasi. Peserta didik akan mendapatkan hasil belajar yang baik, setelah melaksanakan proses pembelajaran (Daryanto, 2011). Pengertian di atas dapat dijelaskan bahwa hasil belajar ranah kognitif dapat meningkatkan kemampuan intelektual. Penggunaan suatu strategi yang baik dan menyenangkan akan meningkatkan daya ingat .Penggunaan mind map bisa membantu peserta didik untuk lebih berpikir dan mengingat suatu pelajaran dengan konsentrasi yang tinggi.

Berdasarkan latar belakang di atas, diduga bahwa pembelajaran yang menyenagkan (joyfull learning ) dengan mind map pada materi sistem ekskresi diharapkan dapat meningkatkan hasil belajar, yang selama ini jarang digunakan oleh guru. Penulis tertarik untuk mengambil judul pengaruh strategi joyfull learning dengan tehnik mind map terhadap hasil belajar kognitif kelas XI IPA SMA Negeri 6 Bandar Lampung. Penelitian ini akan dilakuan pada semester genap TP.2015/2016. 


\section{METODE}

Peneliti menggunakan metode penelitian eksperimen karena peneliti akan mencari pengaruh treatment (perlakuan) tertentu. Quasy Experimental Design yaitu desain ini memiliki kelompok kontrol tetapi tidak berfungsi sepenuhnya untuk mengontrol variabel-variabel luar yang mempengaruhi pelaksanaan eksperimen ( Sugiyono, 2013)

Dalam penelitian ini responden dikelompokkan menjadi dua kelompok. Kelompok pertama adalah kelompok eksperimen, yaitu peserta didik yang mendapat perlakuan. Kelompok kedua adalah kelompok kontrol. Jenis penelitian menggunakan nonequivalent control group design yaitu kelompok eksperimen dan kelompok kontrol tidak dipilih secara random.Penelitian ini dilakukan di SMA Negeri 6 Bandar Lampung. Populasi dalam penelitian ini adalah peserta didik kelas XI SMA Negeri 6 Bandar Lampung. Tahun Pelajaran 2015/2016 sebanyak 3 kelas yang terdiri dari XI IPA 1, XI IPA 2 dan XI IPA 3. Subjek penelitian ini adalah siswa kelas XI IPA 1 sebagai kelas eksperimen dan kelas XI IPA 3 sebagai kelas kontrol. Pengambilan sampel Tehnik sampling merpakan tehnik pengumpulan sampel, atau cara untuk menentukan sampel. Dalam pengambilan kelas eksperimen dan kontrol, tehnik sampling yang digunakan dalam pengambilan kelas kontrol adalah probability sampling dengan tehnik Cluster Random Sampling yaitu pengambilan sampel dari populasi secara acak kelas tanpa memperhatikan strata yang ada dalam populasi itu karena peserta didik dianggap memiliki kemampuan yang sama. 
Penelitian ini terdiri dari dua tahap, yaitu prapenelitian dan pelaksanaan penelitian. Adapun langkah-langkah dari tahap tersebut adalah: a) Membuat surat izin pra survey ke Fakultas Tarbiyah dan Keguruan untuk melakukan penelitian. b) Mengadakan obsevasi ke sekolah tempat diadakannya penelitian untuk mendapatkan data serta informasi tentang keadaan kelas yang akan diteliti. c) Menetapkan kelas kontrol dan kelas eksperimen untuk mendapatkan sampel penelitian dengan cara diundi atau diambil secara acak. d) Menyusun rencana pembelajaran dengan strategi joyfull learning dengan model mind map untuk materi sistem ekskresi. e) Membuat perangkat pembelajaran yang terdiri dari silabus, rencana pelaksanaan pembelajaran (RPP), dan soal instrumen. f) Menyusun instrument penelitian yaitu tes hasil belajar ranah kognitif peserta didik sebanyak 20 soal. g) Memperkenalkan strategi. joyfull learning dengan mind map di kelas eksperimen dan menjelaskan materi yang akan dipelajari saat penelitian. Langkah-langkah kegiatan Kelas eksperimen yaitu: 1) Mempersiapkan mind map yang akan ditampilkan (terlampir) 2) Mempersiapkan pretest pada materi sistem ekskresi dengan jumlah 15 soal. 3) Sebelum memulai pelajaran pendidik sudah memberitahukan alat dan bahan seperti kertas, pensil warna untuk membuat mind map di kelas. 4) Pertemuan pertama akan membahas tentang pengertian, alat-alat ekskresi, dan pembentukan urine kemudian, pertemuan kedua membahas kelainan penyakit. 5) Pendidik menampilkan peta pikiran sesuai dengan konsep yang akan diberikan pada peserta didik sebelum mengerjakan mind mapnya masing-masing. 6) Peserta didik menyiapkan alat-alat dan konsep yang akan digunakan untuk pembuatan mind map. 7) Sebelum pemberian tugas 
tersebut peserta didik sudah siap bermain warna di atas kertas kosong tersebut menggunakan warna atau pensil warna, dan membuat cabang-cabang catatan semenarik mungkin sehingga tidak membosankan dan merangsang semangat belajar mereka. 8) Peserta didik membuat mind map sesuai tema yang telah diberikan dan mereka bebas untuk membuat peta pikiran sesuai dengan keinginan mereka tetapi tidak keluar dari tema yang telah diberikan oleh fasilitator. 9) Jika peserta didik mendapat kesulitan pendidik akan membantu meluruskan masalah yang dialami peserta didik dan peserta didik saling membantu dalam menyelesaikan tugas tersebut. 10) Setelah peserta didik selesai mengerjakan mind map tersebut dikumpul untuk dinilai sesuai kriteria dan acuan nilai mind map. Pendidik dan peserta didik bersama-sama mengoreksi hasil kerjanya masingmasing untuk dihitung seseuai dengan kriteria perhitungan nilai mind map. Penilaian mind map tentang materi sistem ekskresi tersebut dapat dinilai dengan kriteria penilaian mind map yang sudah ada yaitu kriteria yang dinilai meliputi concept link, cross link, hierarchies, examples, invalid component, pictures dan colors Langkah kegiatan pada kelas kontrol 1). Mempersiapkan pretest pada materi sistem ekskresi dengan jumlah 15 soal. 2) Pertemuan pertama akan membahas tentang pengertian, alat-alat ekskresi, dan pembentukan urine kemudian, pertemuan kedua membahas kelainan penyakit. 3)Jika peserta didik mendapat kesulitan pendidik akan membantu meluruskan masalah yang dialami peserta didik dan peserta didik saling membantu dalam menyelesaikan tugas tersebut. 4) Guru bersama peserta didik menyimpulkan materi yang telah dipelajari. 5)Pendidik memberikan posttest dalam jumlah 15 soal. 
Tahap akhir penelitian pada kali ini adalah: 1)Mengolah data yang diperoleh berdasarka perhitungan data yang didapat selam tahapan penelitian. 2) Melakukan analisis terhadap seluruh hasil data penelitian yang diperoleh selama penelitian. 3) Menyimpulkan hasil analisis data.4) Menyusun laporan penelitian. Secara keseluruhan gambaran kegiatan pada kelas kontrol adalah:

Metode pengumpulan data dalam penelitian ini yaitu dengan menggunakan metode wawancara, dokumentasi dan tes. Metode wawancara digunakan untuk observasi awal, metode dokumentasi digunakan untuk mencari data-data untuk mengetahui gambaran umum sekolah yang diteliti dan metode tes digunakan digunakan untuk mengetahui peningkatan hasil belajar siswa. Tes yang digunakan untuk mengukur banyaknya pengetahuan yang diperoleh individu dari satu bahan pelajaran yang terbatas pada tingkat tertentu. Peneliti menggunakan pretes dan posttest sebagai alat penggumpul data dari responden/peserta didik. Tes diberikan pada tahap awal dan tahap akhir. Tes awal digunakan untuk mengetahui kemampuan awal siswa dalam pelajaran Biologi dan tes akhir digunakan untuk mengetahui hasil belajar yang dicapai oleh siswa.

\section{HASIL DAN PEMBAHASAN}

Hasil penelitian dengan judul pengaruhstrategi joyfull learning dengan teknik mind map terhadap hasil belajar peserta didik SMA N 6 Bandar Lampung dimulai dengan peneliti membuat instrumen yaitu kisi-kisi lembar hasil belajar berupa pilihan ganda sebanyak 40 butir dan dianalisis sebelum kegiatan dilakukan. Uji validitas dihitung dengan mencari koefisien korelasi item soal $\left(\mathrm{r}_{\mathrm{xy}}\right)$ 
dengan taraf signifikan $5 \%$ kemudian dibandingkan nilainya dengan $\mathrm{t}_{\text {tabel. }}$. Data ditelaah untuk mencari validitas, reliabilitas, tingkat kesukaran dan daya pembeda yang didapatkan 27 butir yang valid dan 13 tidak. Soal yang digunakan dalam penelitian sebanyak 27 soal.

Kedua kelas melakukan kegiatan awal dengan pemberian pretest dan posttest diakhir pembelajaran. Peneliti menjelaskan materi menggunakan mind map di kelas eksperimen, sedangkan kelompok kontrol memakai media power point (ppt). Guru menyampaikan bahan ajar dengan cara yang berbeda bertujuan untuk mengetahui pengaruh penggunaan strategi joyfull learning dengan teknik mind map terhadap hasil belajar kognitif peserta didik. Mind Map yang dihitung terdiri dari komponen nilai konsep, kaitan silang, tingkatan, warna, gambar, contoh yang akan dibandingkan dengan kriteria acuan sebesar 120.

Uji hipotesis dilakukan bertujuan apakah rata-rata kemampuan kognitif kelas eksperimen lebih tinggi dari rata-rata kelas kontrol. Hipotesis yang digunakan adalah uji “t” dengan kriteria pengujian jika $t_{\text {hitung }}<t_{\text {tabel }}$ maka $\mathrm{H}_{0}$ ditolak dan $t_{\text {hitung }}>t_{\text {tabel }} \mathrm{H}_{1}$ diterima. Nilai mind map dan hasil belajar dibandingkan untuk melihat apakah strategi yang digunakan berpengaruh atau tidak dengan melihat kriteria keduanya ditingkat rendah, sedang, atau tinggi.

\section{a) Nilai Pretest dan Posttest Kelas Eksperimen}

\begin{tabular}{|c|c|c|}
\hline Millai & Preres: & Posiriest \\
\hline Tilai tertingei & 73,33 & 93,33 \\
\hline Milai terendifh & $2 \mathrm{ad}$ & 40 \\
\hline Jumiah & $137 \mathrm{rg}$ & 2.300 \\
\hline Fata-rate & 45.99 & 76.006 \\
\hline
\end{tabular}

Sumber. Date Terelah 
Tabel nilai pretest kelas eksperimen yang dijadikan sampel diperoleh angka terendah 20 dan tertinggi 73,33 dengan rata-rata 45,99. Hasil posttest mendapatkan angka terkecil 40 dan terbesar 93,33 serta rataan 76,66. Strategi joyfull dengan mind map dimulai dengan proses pemberian tes awal dan akhir bertujuan untuk mengetahui kemampuan yang dimiliki peserta didik.

\section{b) Nilai Pretest dan Posttest Kelas Kontrol}

Adapun perolehan nilai pretest dan posttest peserta didik:

Hasil Pretest dan Postrest pada Kelas Kontrol
\begin{tabular}{|l|c|c|}
\hline \multicolumn{1}{|c|}{ Nilai } & Pretest & Postrest \\
\hline Nilai terting彑gi & 66,67 & 86.67 \\
\hline Nilai terendah & 20 & 40 \\
\hline Jumlah & 1359 & 1953 \\
\hline Rata-rata & 45.33 & 65.11 \\
\hline
\end{tabular}
Sumber: Data Terolah

Peserta didik yang dijadikan sampel memperoleh nilai paling rendah 20 dan tertinggi 66.67 dengan rata-rata 45,33. Hasil posttest mendapat angka terkecil 40 dan terbesar 86,67 dengan 65,11. Kelas XI IPA 3 menerapkan strategi joyfull learning dengan menggunakan power point dimulai dengan memberikan tes pertama untuk pengetahuan awal peserta didik. Sampel selanjutnya diuji dengan tes akhir untuk mengetahui hasil keseluruhan dari proses pembelajaran.

\section{Perhitungan Mind Map}

Adapun hasil perhitungan mind map perkelompok pada kelas eksperimen adalah sebagai berikut: 
Tahel 21.

Hasil Rata-Rata Perhitungan Mind Map Perkelompok Kelas Eksperimen
\begin{tabular}{|c|c|c|c|}
\hline Kelompok & Hasil & Presentase & Kriteria \\
\hline 1 & 94 & 68 & Tinggi \\
\hline 2 & 81 & 76 & Tinggi \\
\hline 3 & 94 & 78 & Tinggi \\
\hline 4 & 91 & 78 & Tinggi \\
\hline 5 & 97 & 79 & Tinggi \\
\hline \multicolumn{4}{|c|}{ Rata-rata 76 } \\
\hline
\end{tabular}

Sumbex: Data Terolah

Data hasil perhitungan mind map perkelompok dengan rata-rata 78 tergolong dalam kriteria tinggi. Strategi joyfull learning dengan mind map yang digunakan hasilnya lebih baik dibandingkan menggunakan power point. Teknik ini pun dapat digunakan sebagai variasi dalam proses belajar mengajar.

\section{Uji Prasyarat Hipotesis}

Uji hipotesis statistik yang digunakan penelitian ini adalah Uji-t. Adapun prasyarat-prasyarat yang harus dipenuhi sebelum menggunakan Uji-t adalah sebagai berikut :

\section{Uji Normalitas}

Uji normalitas digunakan untuk mengetahui apakah sampel berasal dari populasi yang berdistribusi normal atau tidak. Data yang dihitung dalam penelitian menggunakan metode Lillifors dengan taraf signifikan 5\%. Hasil perhitungan uji kelas ekseperimen dan kelas kontrol dapat dilihat pada tabel berikut: 


\begin{tabular}{|c|c|c|c|c|c|c|}
\hline \multicolumn{7}{|c|}{$\begin{array}{c}\text { Tabel } 22 \\
\text { Hasil Uji, Normalitas Data Hasil Belajar Kognitif Pretest }\end{array}$} \\
\hline No & Kelompok & $\mathbf{N}$ & $\mathbf{L}_{\text {bitung }}$ & $\mathrm{L}_{\text {tabel }}$ & Keterangan & Keputusan uji \\
\hline$\underline{1}$ & Eksperimen & 30 & 0,109 & 0,159 & $\mathrm{~L}_{\text {matags }}<\mathrm{L}_{\text {abee1 }}$ & \multirow{3}{*}{$\begin{array}{l}\text { Berdistribusi } \\
\text { normal }\end{array}$} \\
\hline 2 & Kontrol & 30 & 0,143 & 0.159 & $\mathrm{~L}_{\text {bituag }}<\mathrm{L}_{\text {abbel }}$ & \\
\hline \multicolumn{3}{|c|}{ Taraf signifikasi } & \multicolumn{3}{|c|}{$5 \%(0,05)$} & \\
\hline
\end{tabular}

Tabel uji normalitas di atas menunjukkan kelas eksperimen memperoleh $\mathrm{L}_{\text {hitung }}=0,109$ dan $\mathrm{L}_{\text {tabel }}=0,159$ serta kelas kontrol $\mathrm{L}_{\text {hitung }}=0,43$ dan $\mathrm{L}_{\text {tabel }}=0,159$. Data amatan $\mathrm{L}_{\text {hitung }}$ setiap kelompok sama-sama kurang dari $\mathrm{L}_{\text {tabel }}\left(\mathrm{L}_{\text {hitung }}<\mathrm{L}_{\text {tabel }}\right)$, artinya masing-masing sampel berasal dari populasi yang berdistribusi normal.

\section{Uji Homogenitas}

Uji homogenitas digunakan untuk mengetahui apakah kedua sampel memiliki varian yang sama atau tidak. Variasi data penelitian ini dianalisis menggunakan uji Fisher. Adapun hasil dapat dilihat pada tabel berikut in:

\section{Tabel 24}

Rekapitulasi Uji Homogenitas Data Hasil belajar Kognitif

\begin{tabular}{|c|c|c|c|c|c|}
\hline $\mathrm{No}_{0}$ & Kelompok & $\mathrm{F}_{\text {litue }}$ & $\mathrm{F}_{\text {tobls }}$ & Keterangan & Keputusan ud \\
\hline 1 & Protert & 1.652 & 1.854 & $F_{\text {bas }}<F_{\text {nal }}$ & \multirow{2}{*}{$\mathrm{H}_{0}$ diterima } \\
\hline 2 & Postert & 1.852 & 1.854 & Fbtan $<F_{\text {thal }}$ & \\
\hline \multicolumn{6}{|c|}{ Taraf signifikasi $5 \%(0,05)$} \\
\hline
\end{tabular}

\section{Sumber: Data Terolah}

Nilai $F_{\text {hitung }}$ kelas eksperimen dan kelas kontrol sama-sama kurang dari $\mathrm{F}_{\text {tabel }}\left(\mathrm{F}_{\text {hitung }}<\mathrm{F}_{\text {tabel }}\right)$, pretest 1,652 dan $\mathrm{F}_{\text {tabel }}=1.854$ dan postest $\mathrm{F}_{\text {hitung }}=1,852$ dan $\mathrm{L}_{\text {tabel }}=1.854$. Semua sampel berarti berasal dari varian yang sama sehingga dapat dilakukan sebagai objek penelitian selanjutnya. Data dikatakan homogen 
apabila $\mathrm{F}_{\text {hitung }}<\mathrm{F}_{\text {tabel }}$ artinya, $\mathrm{H}_{0}$ diterima dan tolak $\mathrm{H}_{1}$. Perhitungan selengkapnya tercantum pada lampiran.

\section{Hasil Pengujian Hipotesis Statistik}

Tabel 25

Hasil Uji Hipotesis Pretest Kelas Eksperimen dan Kontrol

\begin{tabular}{|c|c|c|c|}
\hline \multirow{2}{*}{ Karakteristik } & \multicolumn{2}{|c|}{ Kelas } & \multirow{2}{*}{ Keputusan Uji } \\
\hline & Kontrol & Eksperimen & \\
\hline Rata-rata & 45,33 & 45,99 & \multirow{4}{*}{$\begin{array}{c}T_{\text {bitoas }}>\mathrm{T}_{\text {tabe1 }} \\
\left(\mathrm{H}_{\text {ldinterima }}\right)\end{array}$} \\
\hline$T_{\text {bituag }}$ & \multicolumn{2}{|c|}{2,765} & \\
\hline$T_{\text {tabel }}$ & \multicolumn{2}{|c|}{2,001} & \\
\hline Taraf Signifikas $i$ & \multicolumn{2}{|c|}{$5 \%(0,05)$} & \\
\hline
\end{tabular}

Sumber: Data Terolah

Hasil uji hipotesis di atas diperoleh $t_{\text {hitung }}=2,765$ sedangkan $t_{\text {tabel }}$ pada taraf signifikansi $5 \%$ adalah 2,001 $. \mathrm{T}_{\text {hitung }}>\mathrm{t}_{\text {tabel }}$ sehingga $\mathrm{H}_{0}$ ditolak dan $\mathrm{H}_{1}$ diterima artinya, ada perbedaan antara kelas eksperimen dan kelas kontrol pada awal pengetahuan peserta didik.

Tahel 26

Hasil Uji Hipotesis Posttest Kelas Eksperimen dan Kontrol

\begin{tabular}{|c|c|c|c|}
\hline \multirow[b]{2}{*}{ Karakteristik } & \multicolumn{2}{|c|}{ Kelas } & \multirow[b]{2}{*}{ Keputusan Uji } \\
\hline & Eksperimen & Kontrol & \\
\hline Rata-rata & 76,66 & 65,112 & \multirow{4}{*}{$\begin{array}{c}\mathrm{T}_{\text {bihuag }}>\mathrm{T}_{\text {tabel }} \\
\left(\mathrm{H}_{\text {lditerima }}\right)\end{array}$} \\
\hline Thinas & \multicolumn{2}{|c|}{3,625} & \\
\hline$T_{\text {tabel }}$ & \multicolumn{2}{|c|}{2,001} & \\
\hline $\begin{array}{l}\text { Taraf } \\
\text { Signifikasi }\end{array}$ & \multicolumn{2}{|c|}{$5 \%(0,05)$} & \\
\hline
\end{tabular}

Sumber: Data Terolah

Uji hipotesis di atas diperoleh $t_{\text {hitung }}=3,625$ sedangkan $t_{\text {tabel }}$ pada taraf signifikansi $5 \%$ adalah 2,001, hal ini berarti $\mathrm{t}_{\text {hitung }}>\mathrm{t}_{\text {tabel }}$ sehingga $\mathrm{H}_{0}$ ditolak dan $\mathrm{H}_{1}$ diterima. Posttest yang diberikan memiliki perbedaaan nilai antara kelas 
eksperimen dan kelas kontrol serta keputusan uji memenuhi syarat. Hipotesis yang diajukan adalah sebagai berikut:

$\mathrm{H}_{0}: \mu_{1} \quad \mu_{2}$ (Tidak ada pengaruh signifikan strategi joyfull learning dengan teknik mind map terhadap hasil belajar kognitif peserta didik Kelas XI IPA SMA Negeri 6 Bandar Lampung)

$\mathrm{H}_{1}: \mu_{1}>\mu_{2}$ (Terdapat pengaruh signifikan strategi joyfull learning dengan teknik mind map terhadap hasil belajar kognitif peserta didik Kelas XI IPA SMA Negeri 6 Bandar Lampung).

Tabel uji 23 dan 24 menunjukkan bahwa $t_{\text {hitung }}>t_{\text {tabel }}$ yaitu 2,76>2,001 (pretest) dan 3,62 > 2,001 (postest) dan hipotesisnya $\mathrm{H}_{0}$ ditolak, $\mathrm{H}_{1}$ diterima. Rata-rata hasil belajar kognitif biologi yang mendapat pembelajaran melalui strategi joyfull learning dengan mind map lebih baik dibandingkan kelas yang menggunakan strategi joyfull learning menggunakan power point.

\section{PEMBAHASAN}

Kelas eksperimen memperoleh hasil pretest dengan rata-rata 46,99 dan kontrol 45,33. Kedua kelas tersebut interprestasi nilai masih rendah karena belum diterapkannya strategi joyfull learning. Peneliti diawal kegiatan menampilkan contoh mind map saat proses pembelajaran berlangsung. Peserta didik akhirnya menjadi tertarik saat kegiatan berlangsung meskipun begitu ada beberapa yang belum memperhatikan. Pembuatan mind map yang dilakukan secara individu tersebut menyebabkan suasana kelas kurang menyenangkan dan hubungan 
komunikasi antar peserta didik tidak kondusif pada saat kegiatan belajar mengajar.

Kelas eksperimen dilanjutkan pertemuan kedua mind map akan dibuat perkelompok. Peserta didik terlihat kompak dan saling berkomunikasi satu sama lain ketika kegiatan berlangsung, sehingga proses pada pertemuan terakhir ini pun terasa menyenangkan. Peneliti sekaligus sebagai guru menambahkan kuis untuk menambah semangat belajar. Peserta didik banyak yang saling berebut untuk menjawab pertanyaan sehingga menjadi aktif dalam pembelajaran. Hal ini menunjukkan bahwa proses belajar mengajar menjadi menyenangkan dan membuat suasana kelas tidak terasa membosankan pada saat kegiatan berlangsung. Perwakilan kelompok yang sudah mengerjakan akan menjelaskan pada teman-temannya kemudian dinilai sesuai kriteria secara bersama-sama. Perhatikan salah satu mapping kelompok dibawah ini:

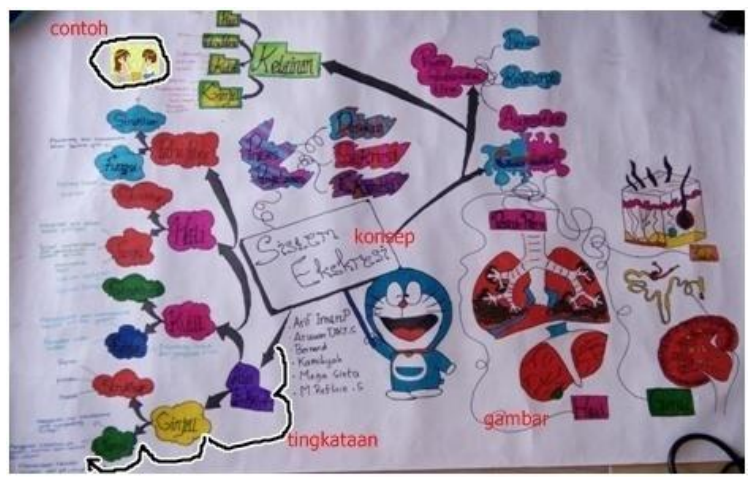

\section{Gambar 4.1}

\section{Hasil Mind Map Kelompok 5}

Nilai rata-rata peta pikiran kelompok lima adalah 102, dengan rincian konsep terdiri dari 3, tingkatan 3, penggunaan warna 12 , kaitan silang 0 , gambar 4 
contoh 1. Semua tim tidak mengisi kaitan silang, meskipun begitu nilai dari keempat kategori sudah termasuk besar untuk melihat pengaruh penggunaan terhadap perlakuan yang diberikan. Nilai peserta didik memperlihatkan kaitan silang yang dibuat masih di bawah mind map acuan. Peserta didik dianggap belum paham konsep sistem ekskresi karena belum dapat membuat kaitan silang meskipun mendapatkan nilai konsep, tingkatan dan warna yang cukup baik. Penggunaan warna pada saat pembuatan mind map memberikan pengaruh besar pada saat pembelajaran. Warna akan membantu peserta didik untuk memperkuat pengajaran dan pembelajaranpun akan menjadi menyenangkan. Hasil perhitungan diperoleh rata-rata keseluruhan sebesar 78 walaupun masih dibawah nilai acuan tetapi rataan masuk kategori tinggi.

Peserta didik saat melaksanaka $\mathrm{n}$ tahapan-tahapan pembuatan mind map bagi mereka tidak terlalu sulit. Pelajar perlu memiliki konsentrasi, kerja sama untuk menghubungkan komunikasi dan menggunakan banyak warna ketika pembuatan akan menjadikan proses pembelajaran dengan suasana menyenangkan.Warna memperkuat pengajaran dan belajar ( Darmansyah,2012). Hal ini dapat dilihat ketika penyiapan alat dan bahan semua bersemangat untuk belajar karena strategi ini belum pernah diterapkan pada materi biologi. Suasana akan terasa menyenangkan tentunya jika kelompok bisa bekerja sama dengan baik dan cepat menyelesaikan kegiatan tersebut.

Kelemahan yang senantiasa terjadi dalam belajar kelompok adalah tidak disiplin sehingga prestasi yang akan dicapai pada peserta didik kurang optimal. Hal ini terjadi jika kelompok tidak mempunyai kedisiplinan dalam belajar seperti 
datang terlambat, mengobrol akan membuang waktu berlalu begitu saja. Kelebihan masing-masing individu pada saat pembuatan mind map dituntut untuk mencari materi untuk mengembangkan potensi diri untuk kesuksesan kelompoknya.

Kelas kontrol diawali dengan pemberian pretest proses pembelajarannya menggunakan strategi joyfull learning, materi ditampilkan dalam bentuk ppt kemudian dicatat. Bahan ajar yang diberikan pada pertemuan pertama pengertian sistem ekskresi, penjelasan tentang organ serta pembentukan zat yang dihasilkan.

Kelas kontrol selanjutnya dipertemuan kedua membahas tentang kelainan penyakit sistem ekskresi dan perbedaan cara pengeluaran zat yang tidak digunakan pada ikan air tawar dengan air laut. Materi ajar saat dijelaskan oleh peneliti masih banyak yang belum memperhatikan, untuk mengatasi masalah tersebut dilakukan tanya jawab terkait pelajaran.

Sampel kelas setelah diberikan perlakuan sebanyak dua kali pertemuan, pada akhir pembelajaran sama-sama diberikan posttest berupa pilihan ganda untuk memperoleh data hasil belajar. Nilai rata-rata kelas eksperimen sebesar 76,66 dan rataan kelas kontrol berjumlah 65,11 . Nilai yang didapat terbukti bahwa kelas eksperimen mendapatkan hasil yang lebih tinggi dibandingkan kelas kontrol.

Strategi joyfull learning akan memberikan pengaruh pada hasil belajar dengan melihat perbedaan nilai rata-rata kelas kontrol dan kelas eksperimen. Membangun hubungan dan meningkatkan komunikasi, mengurangi stress, membuat pembelajaran menjadi menarik dan meningkatkan daya ingat pada suatu pembelajaran. Peserta didik juga bisa meningkatkan pengetahuan serta wawasan 
secara mandiri saat melaksanakan pelatihan karena mereka mencari inti materi secara bebas.

Nilai hasil belajar kognitif tersebut akan digunakan untuk menguji kebenaran hipotesis. Data diperoleh dari dua kelas untuk melakukan perhitungan uji prasyarat berupa uji normalitas dan uji homogenitas serta dilanjut dengan uji t. Setiap kelompok uji diperoleh nilai $\mathrm{L}_{\text {hitung }}$ kurang dari $\mathrm{L}_{\text {tabel }}\left(\mathrm{L}_{\text {hitung }}<\mathrm{L}_{\text {tabel }}\right)$. Kedua kelas berarti berasal dari populasi yang berdistribusi normal.

Uji prasyarat dilanjutkan dengan uji homogenitas untuk mengetahui apakah populasi penelitian mempunyai variansi yang sama atau tidak. Penulis menunjukkan berdasarkan hasil perhitungan yang dilakukan diperoleh $\mathrm{F}_{\text {hitung }}$ kurang dari $\mathrm{F}_{\text {tabel }}\left(\mathrm{F}_{\text {hitung }}<\mathrm{F}_{\text {tabel }}\right)$. Populasi berarti berasal dari varians (populasi) yang sama atau homogen $\left(\mathrm{H}_{0}\right.$ diterima dan tolak $\left.\mathrm{H}_{1}\right)$, jika telah terpenuhi maka dianalisis dengan uji t untuk melihat sejauh mana pengaruh yang dihasilkan. Nilai $t_{\text {hitung }}$ adalah 2,765 dan harga $\mathrm{t}_{\text {tabel }}$ dihitung $\mathrm{dk}=30+30 \quad 2=58$, maka $\mathrm{t}_{\text {tabel }} 2,001$ dengan kata lain $\mathrm{H}_{1}$ diterima dan tolak $\mathrm{H}_{0}$. Kedua kelas tersebut berarti memiliki kondisi awal yang tidak sama dalam kemampuan kognitif peserta didik. Hal ini terbukti bahwa $t_{\text {hitung }}>t_{\text {tabel }}$ terdapat perbedaan nilai secara signifikan kemampuan hasil belajar kognitif . Sampel dapat diberi perlakuan berbeda untuk mengukur sejauh mana pengaruh yang dihasilkan.

Analisis data yang telah dilakukan, setelah diberi perlakuan diperoleh besarnya $t_{\text {hitung }}=3,625$ dengan harga $t_{\text {tabel }}$ dihitung $\mathrm{dk}=30+30=58, \quad$ maka harga $t_{\text {tabel }} 2,001$ dengan taraf signifikan $5 \% t_{\text {hitung }}>t_{\text {tabel }}$ yaitu $3,625>2,001$. $\mathrm{H}_{0}$ ditolak dan $\mathrm{H}_{1}$ diterima, artinya terdapat perbedaan rata-rata secara signifikan 
antara kemampuan kognitif peserta didik kelas eksperimen dengan kelas kontrol.

Data akhir yang sudah diperoleh pada kelas eksperimen yaitu rataan mind map 78 dan $\bar{x}$ hasil belajar 76,66 sama-sama kategori tinggi serta keputusan uji hipotesis $\mathrm{t}_{\text {hitung }}>\mathrm{t}_{\text {tabel }}$. Kelas kontrol memiliki nilai rata-rata akhir 65,11 walaupun termasuk dalam tingkat tinggi, tetapi kelas yang diberi perlakuan memperoleh nilai terbanyak dibanding kelas kontrol. Strategi joyfull learning yang digunakan berarti memiliki pengaruh terhadap kemampuan kognitif setelah diberi perlakuan berbeda.

\section{KESIMPULAN}

Berdasarkan analisis data dan pembahasan yang diperoleh dari pengujian hipotesis serta pengalaman yang penulis dapatkan selama penelitian, penulis menyimpulkan bahwa terdapat pengaruh kemampuan hasil belajar kognitif yang mendapatkan pengajaran dengan menggunakan strategi pembelajaran joyfull learning dengan teknik mind map peserta didik kelas XI IPA SMA Negeri 6 Bandar Lampung. Peningkatan hasil belajar tersebut dipengaruhi oleh faktor eksternal seperti penggunaan strategi pembelajaran juga disebabkan oleh faktor internal seperti kemampuan kognitif yang bisa mempengaruhi daya ingat pada peserta didik saat proses pembelajaran berlangsung.

\section{SARAN}

Berdasarkan hasil analisis data dan uji hipotesis yang secara statistik telah dibuktikan kebenarannya dengan nyata, maka dalam penelitian ini diberikan saran-saran sebagai berikut: 
1. Bagi guru, pembelajaran biologi menggunakan strategi joyfull learning dengan tehnik mind map dapat digunakan sebagai alternatif dalam mengajar agar peserta didik merasa nyaman, menyenangkan dan berinteraksi dalam diskusi antarkelompok.

2. Bagi peserta didik dapat menemukan konsep materi sendiri sehingga pengetahuan yang diperoleh peserta didik akan tertinggal lama dan mudah diingat dan hasil belajar peserta didik bisa meningkat.

3. Bagi penulis, selanjutnya jika ingin strategi pembelajaran menyenangkan (Joyfull Learning) dengan teknik mind map, penulis harus lebih mampu mengoptimalkan kelas agar pembelajaran berlangsung efektif dan efisien.

\section{DAFTAR PUSTAKA}

Adiarti, Wulan.2012. Penerapan Strategi Mind Mapping Untuk Meningkatkan Pemahaman Mahasiswa . Journal of Early Childhood.

Adi Susilo, dan Sutarjo. 2013. Pembelajaran Nilai Karakter. Jakarta: Rajawali Pers.

Amin, Moh.2003. Biologi. Jakarta: Balai Pustaka.

Darmansyah. 2012. Strategi Pemblajaran Menyenangkan Dengan Humor. Jakarta: Bumi Aksara.

Daryanto. 2011. Evaluasi Pendidikan. Jakarta: Rineka Cipta.

Hamzah, dan Noerdin. 2012. Belajar dengan Pendekatan PAILKEM. Jakarta: Bumi Aksara.

Hamalik, Oemar. 2014. Kurikulum dan Pembelajaran. Bandung: Bumi Aksara

Hendry, Samuel, 2011. Cara Praktis Menjadi Kreatif dalam 14 Hari. Yogyakarta

Joko, Muhammad S. 2005. Desain Eksperimen dan Pengolahan Data Penelitian Aplikasi SPSS: Yogyakarta. 
Mujiano, dan Dimayanti. 2006. Belajar dan Pembelajaran. Jakarta : Rineka Cipta.

Netriwati, et al. 2012. Teori Belajar dan Pembelajaran. Lampung : IAIN Raden

Saleh, Andri. 2008. Kreatif Mengajar dengan Mind Map. Bandung: Tinta Emas

Slameto. 2013. Belajar dan Faktor-faktor yang Mempengaruhi. Jakarta:Rineka Cipta

Sudaryono. 2013. Pengembangan Instrumen Penelitian Pendidikan. Yogyakarta: Graha Ilmu

Sugiyono. 2013. Metode Penelitian. Bandung: Alfabeta

----------. 2012. Metode Penelitian Kualitatif, Kuantitatif dan $R \& D$. Bandung: Alfabeta

Suparyo, Yossi. 2005. Undang-undang Sistem Pendidikan Nasional .Yogyakarta: Media.

Indrawati, Sutarto. 2013. Strategi Belajar Mengajar. Jember: University Press.

Syah, Muhibbin. 2003. Psikologi Belajar. Jakarta: PT.Raja Persada.

Syaodih, Nana.2005. Landasan Psikologi Proses Pendidikan. Bandung: Remaja Rosdakarya.

Zaini dan Jamrah. 2006. Strategi Belajar Mengajar. Jakarta: Rineka Cipta. 